\title{
Effect of Lime and Boron on Growth and Yield of Sprouting Broccoli under Sub-Himalayan Foot Hills of West Bengal, India
}

\author{
Riman Saha Chowdhury*, Monika Kumari, J.C. Jana, \\ Shibnath Basfore and Subhamoy Sikder
}
Department of Vegetable and Spice Crops, Faculty of Horticulture, Uttar Banga Krishi Viswavidyalaya (UBKV), Pundibari, Coochbehar-736165, West Bengal, India

*Corresponding author

\begin{tabular}{l} 
Ke y w o r d s \\
$\begin{array}{l}\text { Boron, Lime, } \\
\text { Sprouting broccoli }\end{array}$ \\
Article Info \\
$\begin{array}{l}\text { Accepted: } \\
\text { 17 December } 2018 \\
\text { Available Online: } \\
\text { 10 January } 2019\end{array}$ \\
\hline
\end{tabular}

An experiment was conducted to determine the suitable combination of lime and boron during winter season months under terai region of West Bengal. The experiments were carried out at Instructional Farm, UBKV, Pundibari, Coochbehar during 2015-16. The experiment consisted of two levels of lime $(0$ and $450 \mathrm{~kg} / \mathrm{ha})$ and six levels of Boron (0kg/ha, $7.5 \mathrm{~kg} / \mathrm{ha}, 15 \mathrm{~kg} / \mathrm{ha}, 22.5 \mathrm{~kg} / \mathrm{ha}, 30 \mathrm{~kg} / \mathrm{ha}$ and $37.5 \mathrm{~kg} / \mathrm{ha})$. Each experiment was conducted in Asymmetrical factorial Randomized Block Design with 3 replications by using lime, boron and lime-boron interaction significantly that resulted increase in plant growth and yield as compared to the experiments conducted without lime, boron, and their interaction that is in control with the applicable dose of NPK. Similarly, the use of lime and boron significantly increased plant height and number of eaves by $18.04 \%$ and 34.00 $\%$ respectively over the control. It was found that use of lime and boron @ $450 \mathrm{~kg} / \mathrm{ha}$ and $7.5 \mathrm{~kg} / \mathrm{ha}$ gave highest number of leaves (23), and use of lime and boron @ $450 \mathrm{~kg} / \mathrm{ha}$ and $30 \mathrm{~kg} / \mathrm{ha}$ gives maximum fresh weight $(674.32 \mathrm{~g})$ and head diameter $(17.57 \mathrm{~cm})$ in F1 hybrid Green Magic variety of sprouting broccoli. Combined use of lime $(450 \mathrm{~kg} / \mathrm{ha})$ and boron $(30 \mathrm{~kg} / \mathrm{ha})$ recorded $56.09 \%$ higher yield $(16.16 \mathrm{t} / \mathrm{ha})$ over the control (5.93 t/ha).

\section{Introduction}

Broccoli (Brassica oleracea var italica L.) is one of the cole crops belonging to the family cruciferae. It is a binniel crop and originated from West Europe. Although originated from temperate region, it is well distributed to both the sub-tropical and tropical areas of India. Broccoli is nutritious vegetable which is fairly rich in vitamin $\mathrm{A}$ and $\mathrm{C}$, and minerals namely, calcium, phosphorus and iron. So, it can contribute significantly to improve our diet. It is more nutritious than other cole crops such as cabbage, cauliflower and kohlrabi. Broccoli is grown by a small percentage of home gardens in India during the winter season. It is environmentally better adapted than cauliflower as reported to withstand comparatively higher temperature. The growth and yield of broccoli in India are 
seriously impeded compared to that of other countries. The main reason for such poor growth and yield of broccoli is due to the lack of judicious application of fertilizers, and proper cultural and management practices. Boron is considered as a potential micro nutrient that carries out various functions for growth and development. Application of boron significantly increases curd diameter, weight of curd, yield and quality of cauliflower (Kumar et al., 2002). In cole crops like cauliflower and broccoli, boron requirement is high. It is essential for translocation of sugars, starches, nitrogen and sulphur. Lime is an important factor in the nutrition of broccoli as the crop generally makes its best growth when the soil $\mathrm{pH}$ is 6.87.0 as a control for clubrot, a soil-born slime mold which can seriously affect production of cole crops. The soil of terai agro climatic region of West Bengal is generally sandy loam in texture and acidic reaction with $\mathrm{pH}$ range of 5.40 to 6.20 . Due to high rainfall in mid hills, leaching of nutrients and micronutrients is a common incidence leading to frequent deficiency of the elements like calcium and boron in soil. Therefore, it should be overcome to get sustained and increased production. In order to formulate the correct dose of boron and lime for getting higher growth and curd yield in small and scattered land holding of terai area, the present investigation was undertaken with the following.

\section{Materials and Methods}

The field experiments were carried out at Horticultural Farm of Uttar Banga Krishi Viswavidyalaya, Pundibari, Cooch Behar, West Bengal, situated at $26^{\circ} 40^{\prime} \mathrm{N}$ latitude and $89^{\circ} 38^{\prime} \mathrm{E}$ longitudes with average altitude of $43 \mathrm{~m}$ above the mean sea level (MSL) and soil $\mathrm{pH}$ 5.5-6.5 during autumn-winter season. In this experiment two important micronutrients viz., lime and boron along with their combinations were applied during final land preparation on locally popular cultivar "Green Magic" of broccoli. The experiment consisted of two levels of lime ( 0 and 450 $\mathrm{kg} / \mathrm{ha})$ and six levels of Boron $(0 \mathrm{~kg} / \mathrm{ha}, 7.5$ $\mathrm{kg} / \mathrm{ha}, 15 \mathrm{~kg} / \mathrm{ha}, 22.5 \mathrm{~kg} / \mathrm{ha}, 30 \mathrm{~kg} / \mathrm{ha}$ and 37.5 $\mathrm{kg} / \mathrm{ha}$ ). The plants for data collection were randomly selected from middle rows of each unit plot avoiding border effects, except for the yield of curds, which was recorded plot wise. Data were collected in respect of the following parameters to assess plant growth; yield attributed and yield as affected by different treatment of the experiment. Data on height of the plant, spread of the plant, length of the leaves and number of the leaves of the plants were collected at 30, 45, 60 days after transplanting (DAT). Length and breadth of the largest leaf were collected at 60 DAT. All other parameters like days required for curd initiation, diameter of primary curd, weight of primary curd, weight of secondary curd per plant, yield per plot and bio-chemical traits viz. vitamin A (mg/ 100g) and ascorbic acid of head $(\mathrm{mg} / 100 \mathrm{~g})$ were recorded at harvest. The observations recorded from different treatments in the field as well as in the laboratory were subjected to statistical analysis by adopting the method suggested by Panse and Sukhatme (1998). The treatment variations were tested for significance by adopting $\mathrm{F}$ test (Cox, 1958). The calculated F value was compared with the table value. If $F$ test was found to be significant then standard error of mean and critical differences was calculated to find out the superiority of one entry over others. For determination of critical difference at 5\% level of significance (Fisher and Yates, 1963) table was consulted.

\section{Results and Discussion}

\section{Growth parameters}

The effect of lime on plant height of broccoli was found to be significant. Data have been 
presented in table 1 . The tallest plant of height of $37.80 \mathrm{~cm}$ in Sprouting broccoli was recorded with the use of lime at the rate of $450 \mathrm{~kg} / \mathrm{ha}$ that was $10.31 \%$ higher over that at no lime application. The effect of boron on plant height of Sprouting broccoli was found to be significant. Data have been presented in table 1. The tallest plant of $39.80 \mathrm{~cm}$ in Sprouting broccoli was recorded with the use of Boron at the rate of $22.5 \mathrm{~kg} / \mathrm{ha}$ that was $18.04 \%$ higher over that at no boron concentration. The interaction effect of lime and boron was also found to be significant. The data have been presented in table 1 . The tallest plant of height of $42.90 \mathrm{~cm}$ in Sprouting broccoli was recorded with the use of lime at the rate of $450 \mathrm{~kg} / \mathrm{ha}$ and boron at the rate of $22.5 \mathrm{~kg} / \mathrm{ha}$ the lowest plant height was recorded $34.70 \mathrm{~cm}$ in control condition with no lime and boron concentration only with the recommended dose of NPK. Use of lime and boron recorded $20.11 \%$ increase over no lime and boron concentration. The result showed the plant height gradually increases with time and was highest at interaction effect of lime and boron at 7.5 $\mathrm{kg} / \mathrm{ha}$ and then the value slows down, the variation in plant height, among the treatment might be due to the enhancement in translocation of carbohydrate from the site of synthesis to storage tissue in plant as lime and boron application. Sharma (2002) reported the maximum plant height found $2.5 \mathrm{~kg} \mathrm{~B} / \mathrm{ha}$ in cauliflower.

The effect of lime on the length of the leaf was found to be non-significant. Data have been presented in table 1 . The highest length of leaf of $30.57 \mathrm{~cm}$ in Sprouting broccoli was recorded with the use of lime at the rate of $450 \mathrm{~kg} / \mathrm{ha}$ that was $10.26 \%$ higher over that at no lime application. The effect of boron on length of leaf of Sprouting broccoli was found to be significant. Data have been presented in table 1. The maximum length of leaf of 34.54 $\mathrm{cm}$ in Sprouting broccoli was recorded with the use of Boron at the rate of $15 \mathrm{~kg} / \mathrm{ha}$ that was $25.36 \%$ higher over that at no boron concentration. The interaction effect of lime and boron was found to be non-significant. Data have been presented in table 1. The highest length of leaf of $35.18 \mathrm{~cm}$ in sprouting broccoli was recorded with the use of lime at the rate of $450 \mathrm{~kg} / \mathrm{ha}$ and boron at the rate of $37.5 \mathrm{~kg} / \mathrm{ha}$ that was found to be $31.55 \%$ higher over that of control concentration with no lime and boron. This increase in length of leaf may be due to higher boron and lime content, lime reduces the soil $\mathrm{pH}$ and hence increases the availability of boron to the plant which helps in high vegetative growth reported by Chaudhury and Debnath (2008), Sharma (1999) and Kushwaha et al., (2009).

The effect of lime on the width of the leaf was found to be non-significant Data have been presented in table 1 . The highest width of leaf of $21.59 \mathrm{~cm}$ in sprouting broccoli was recorded with the use of lime at the rate of $450 \mathrm{~kg} / \mathrm{ha}$ that was $9.26 \%$ higher over that at no lime application. The effect of boron on length of leaf of sprouting broccoli was found to be non-significant. Data have been presented in table 1 . The maximum width of leaf of $23.00 \mathrm{~cm}$ in sprouting broccoli was recorded with the use of Boron at the rate of $15 \mathrm{~kg} / \mathrm{h}$ a that was $14.21 \%$ higher over that at no boron concentration. The interaction effect of lime and boron was also found to be nonsignificant. Data have been presented in table 1. The highest length of leaf of $23.89 \mathrm{~cm}$ in sprouting broccoli was recorded with the use of lime at the rate of $450 \mathrm{~kg} / \mathrm{ha}$. and boron at the rate of $15 \mathrm{~kg} / \mathrm{ha}$ that was found to be $21.47 \%$ higher over that of control concentration with no lime and boron. This difference in width of leaf of sprouting broccoli may be due to supply of lime and boron, as lime maintains the soil $\mathrm{pH}$ and boron thus increases the effect by recovering the transpiration rate, stomatal conductance and intercellular $\mathrm{CO}_{2}$ concentration, 
suggesting the involvement of B in stomatal regulation reported by Sharma et al., (1991).

The effect of lime on the number of leaves was found to be significant. Data have been presented in table 1 . The highest number leaves of 22 in sprouting broccoli were recorded with the use of lime at the rate of $450 \mathrm{~kg} / \mathrm{ha}$ that was $10.09 \%$ higher over that at no lime application. The variation in number of leaves of sprouting broccoli in different doses of boron was found to be significant. Data have been presented in table 3. The highest number of leaves of 23 in sprouting broccoli was recorded with the use of Boron at the rate of $15 \mathrm{~kg} / \mathrm{ha}$ that was $26.08 \%$ higher over that at no boron concentration. The variation in number of leaves of sprouting broccoli in different doses of lime and was also found to be significant. Data have been presented in table 3. The highest number of leaves of 25 in sprouting broccoli was recorded with the use of lime at the rate of $450 \mathrm{~kg} / \mathrm{ha}$ and boron at the rate of $7.5 \mathrm{~kg} / \mathrm{ha}$ that was found to be $32.00 \%$ higher over that of control concentration with no lime and boron. This variation in number of leaves may be due to the application of lime and boron, the lime controls the $\mathrm{pH}$ of the soil and hence increase in boron solubility to the soil increasing the vegetative growth and number of leaves Increase in vegetative growth of different crops by boron application was reported by earlier workers Godvindan et al., (1992).

The effect of lime on the spread of the plant has high significant effect. Data have been presented in table 1 . The maximum spread of plant of $62.10 \mathrm{~cm}$ in sprouting broccoli was recorded with the use of lime at the rate of $450 \mathrm{~kg} / \mathrm{ha}$ that was $10.33 \%$ higher over that at no lime application. The effect of boron on spread of plant of Sprouting broccoli was found to be significant. Data have been presented in table 1 . The maximum spread of plant of $62.70 \mathrm{~cm}$ in sprouting broccoli was recorded with the use of Boron at the rate of $37.5 \mathrm{~kg} / \mathrm{ha}$ that was $17.62 \%$ higher over that at no boron concentration. The interaction effect of lime and boron was also found to be significant. Data have been presented in table 1. The maximum spread of plant of $67.45 \mathrm{~cm}$ in Sprouting broccoli was recorded with the use of lime at the rate of $450 \mathrm{~kg} / \mathrm{ha}$ and boron at the rate of $15 \mathrm{~kg} / \mathrm{ha}$ that was found to be $23.60 \%$ higher over that of control concentration with no lime and boron. The treatment of lime at the rate $450 \mathrm{~kg} / \mathrm{ha}$ and boron at $37.5 \mathrm{~kg} / \mathrm{ha}$ which produce the maximum spread of the plant was statistically similar to treatment of lime $450 \mathrm{~kg} / \mathrm{ha}$ and no boron concentration. Correlative response of the crop to vegetative growth and plant spread was probably due to a greater number of leaves produced more photosynthates through enhanced photosynthetic surface area index which might have helped the plant to remain more active for efficient physiological activities for longer period same was reported by Chandra et al., 2007.

\section{Yield parameters}

The application of lime fertilizer has significant effect on the number of days required to harvest after transplanting. Data have been presented in table 1 . The highest number of days required for harvesting was recorded to 60 days in sprouting broccoli was recorded with the use of lime at the rate of $450 \mathrm{~kg} / \mathrm{ha}$ which was found to be $11.23 \%$ higher over that of no lime concentration. The application of boron fertilizer at different doses has significant effect on the number of days required to harvest after transplanting. Data have been presented in table 1. The highest number of days required for harvesting was recorded to 62 days in sprouting broccoli was recorded with the use of boron at the concentration of $15 \mathrm{~kg} / \mathrm{ha}$ which was found to be $14.45 \%$ higher over 
that of boron $7.5 \mathrm{~kg} / \mathrm{ha}$. The interaction effect of boron and lime fertilizer at different doses has significant effect on the number of days required to harvest after transplanting. Data have been presented in table 1 . The highest number of days for harvesting was recorded to 63 days in sprouting broccoli which was recorded with the use of lime concentration of $450 \mathrm{~kg} / \mathrm{ha}$ and boron concentration of 15 $\mathrm{kg} / \mathrm{ha}$ which was found to be $21.11 \%$ over the control, this difference may be due to environment factor, physiological effect of boron.

The effect lime fertilizer has the significant effect on the fresh weight of the head of sprouting broccoli. Data have been presented in table 1. The maximum fresh weight of sprouting broccoli was recorded $452.40 \mathrm{~g}$ with the use of lime at $450 \mathrm{~kg} / \mathrm{ha}$ that was found to be $20.27 \%$ higher over the no lime concentration. The effect of boron at different doses has the significant effect on the fresh weight of the head of sprouting broccoli. Data have been presented in table 1 . The maximum fresh weight of sprouting broccoli was recorded $450.43 \mathrm{~g}$ with the use of boron at 30 $\mathrm{kg} / \mathrm{ha}$ that was found to be $21.85 \%$ higher at no boron application. The interaction effect of lime and boron has also significant effect on the fresh weight of the head of Sprouting broccoli. Data have been presented in table 1 . The maximum fresh weight of sprouting broccoli was recorded $674.32 \mathrm{~g}$ with the use of lime at $450 \mathrm{~kg} / \mathrm{ha}$ and boron at $30 \mathrm{~kg} / \mathrm{ha}$ that was found to be $50.32 \%$ higher at control means no lime and boron application. The variation in fresh weight of broccoli may be due to application of boron involved in transportation of sugar across cell membranes, cellular differentiation and development, nitrogen metabolism, active salt absorption, water retention etc. Lime restricted boron fixation by raising $\mathrm{pH}$ towards neutrality which helped in increasing boron availability to the plants the same result was found by Sharma (2002), while working in yellow sarson Saha et al., (1999).

The application of lime causes significant effect on the head diameter of the sprouting broccoli. Data have been presented in table 1. The highest head diameter $14.11 \mathrm{~cm}$ was recorded with lime $450 \mathrm{~kg} / \mathrm{ha}$ which was $25.64 \%$ higher over the no lime application. The effect of different doses boron has significant effect on the head diameter of sprouting broccoli. Data have been presented in table 1. The highest head diameter 15.06 $\mathrm{cm}$ was recorded with boron at $15 \mathrm{~kg} / \mathrm{ha}$ which was $28.80 \%$ higher over the no boron concentration. This result is supported by Sanjay et al., (2002) as who found that Mo and B application significantly increased curd diameter, weight and yield of broccoli. The interaction effect of different doses of lime and boron has significant effect on the head diameter of sprouting broccoli. Data have been presented in table 1 . The highest head diameter $17.57 \mathrm{~cm}$ was recorded with interaction effect of lime at $450 \mathrm{~kg} / \mathrm{ha}$ and boron at the rate of $7.5 \mathrm{~kg} / \mathrm{ha}$ which was recorded $48.60 \%$ higher over the control means no lime and boron concentration. The higher diameter of the head of sprouting broccoli may be due the application of boron which helps in sugar translocation across the cell membrane and hence helps in cell differentiation and development by Sharma (2002) and Jana (2004).

The application of lime causes significant effect on the head dry weight of the sprouting broccoli. Data have been presented in table 1. The highest head dry weight $22.92 \mathrm{~g}$ was recorded with no lime application which was $11.12 \%$ higher over lime of $450 \mathrm{~kg} / \mathrm{ha}$ application. The effect of different doses boron has significant effect on the head dry weight of sprouting broccoli. Data have been presented in table 1 . The highest head dry weight $25.94 \mathrm{~g}$ was recorded with boron at 15 
$\mathrm{kg} / \mathrm{ha}$ which was $37.77 \%$ higher over the no boron concentration. The interaction effect of different doses of lime and boron has significant effect on the head dry weight of sprouting broccoli. Data have been presented in table 1 . The highest head dry weight of $26.59 \mathrm{~g}$ was recorded with no lime and boron at the rate of $15 \mathrm{~kg} / \mathrm{ha}$ which was recorded $38.51 \%$ higher over the control means no lime and boron concentration.

The results of application of lime on the dry weight of head of sprouting broccoli were significantly. Data have been presented in table 1. The maximum dry weight of $9.22 \%$ of sprouting broccoli was recorded at lime of $450 \mathrm{~kg} / \mathrm{ha}$ that was found $17.23 \%$ higher over the no lime concentration. The results of application of different dose of boron on the dry weight of head sprouting broccoli were significant. Data have been presented in table 1. The maximum dry weight of $10.49 \%$ of sprouting broccoli was recorded at $15 \mathrm{~kg} / \mathrm{ha}$ of boron application which was found 28.50 $\%$ higher over the no boron concentration. The results of application of different doses of lime and boron on the dry weight of head of sprouting broccoli were found to be significant. Data have been presented in table 1. The maximum dry weight of $11.31 \%$ of sprouting broccoli was recorded at lime 450 $\mathrm{kg} / \mathrm{ha}$ and boron at the rate of $15 \mathrm{~kg} / \mathrm{ha}$ which was found to be $33.77 \%$ higher over the control condition the value of fertilizer application of lime and boron at the rate of $450 \mathrm{~kg} / \mathrm{ha}$ and $15 \mathrm{~kg} / \mathrm{ha}$ was found statically similar to the fertilizer concentration at lime $450 \mathrm{~kg} / \mathrm{ha}$ and boron at $37.5 \mathrm{~kg} / \mathrm{ha}$.

The effect of lime fertilizer has the significant effect on the weight of the secondary shoots sprouting broccoli. Data have been presented in table 2. The maximum weight of secondary shoot of sprouting broccoli was recorded $219.16 \mathrm{~g}$ with the use of lime at $450 \mathrm{~kg} / \mathrm{ha}$ that was found to be $26.53 \%$ higher over the no lime concentration. The effect of boron at different doses has the significant effect on the weight of the secondary shoots of sprouting broccoli. Data have been presented in table 2. The maximum weight of secondary shoots of sprouting broccoli was recorded $215.25 \mathrm{~g}$ with the use of boron at $15 \mathrm{~kg} / \mathrm{ha}$ that was found to be $39.36 \%$ higher at no boron application. The interaction effect of lime and boron has also significant effect on the weight of secondary shoots of sprouting broccoli. Data have been presented in table 2 . The maximum weight of secondary shoots of sprouting broccoli was recorded $241.60 \mathrm{~g}$ with the use of lime at $450 \mathrm{~kg} / \mathrm{ha}$ and boron at $15 \mathrm{~kg} / \mathrm{ha}$ that was found to be $55.05 \%$ higher at control means no lime and boron application. This may be due to boron doses which increase the head size and physiology of plant of sprouting broccoli.

The effect of lime fertilizer has the significant effect on yield per plot of sprouting broccoli. Data have been presented in table 2. The maximum yield of sprouting broccoli was recorded $6.02 \mathrm{~kg}$ with the use of $450 \mathrm{~kg} / \mathrm{ha}$ lime that was found to be $56.31 \%$ higher over the no lime concentration. The effect of boron at different doses has the significant effect on yield of sprouting broccoli. Data have been presented in table 3. The maximum yield of sprouting broccoli was recorded $5.35 \mathrm{~kg}$ with the use of boron at $\mathrm{kg} / \mathrm{ha}$ that was found to be $45.79 \%$ higher at no boron application. Similar result was also found in the research of Brahma et al., 2002. The interaction effect of lime and boron has also significant effect on the yield of sprouting broccoli. Data have been presented in table 3 . The maximum yield of sprouting broccoli was recorded $6.43 \mathrm{~kg}$ with the use of lime at $\mathrm{kg} / \mathrm{ha}$ and boron at 30 $\mathrm{kg} / \mathrm{ha}$ that was found to be $56.09 \%$ higher at control concentration. These findings are in agreement with those of Mishra and Singh (1984).Kumar et al., (2002) reported that molybdenum and boron application 
significantly increased curd diameter, weight and yield of cauliflower. Borax at $10 \mathrm{~kg} / \mathrm{ha}$ increased the yield by $32 \%$. Pizetta et al., (2005) observed that quality of the curds decreases when 2 or $6 \mathrm{~kg} / \mathrm{ha}$ of $\mathrm{B}$ were applied to cauliflower. Prasad et al., (2000) stated that under B application Pusa Snowball B1 gave the highest yield (13.4 t/ha). Application of B significantly increased the yield by (133\%), curd weight, curd diameter, number of marketable curds. Kotur et al., (1990) showed that the yield of curds of cauliflower increased from $4.0 \mathrm{t} / \mathrm{ha}$ in the control to the highest yield of $12.93 \mathrm{t} / \mathrm{ha}$ at 10 $\mathrm{kg}$ borax/ha and then decreased.

The effect of lime fertilizer has the significant effect on yield of sprouting broccoli. Data have been presented in table 3 . The maximum yield of sprouting broccoli was recorded 5.12 $\mathrm{t} / \mathrm{ha}$ with the use of $450 \mathrm{~kg} / \mathrm{ha}$ lime that was found to be $13.47 \%$ higher over the no lime concentration. The effect of boron at different doses has the significant effect on yield of sprouting broccoli. Data have been presented in table 3. The maximum yield of sprouting broccoli was recorded $7.0 \mathrm{t} / \mathrm{ha}$ with the use of boron at $15 \mathrm{~kg} / \mathrm{ha}$ that was found to be 33.28 $\%$ higher at no boron application. The interaction effect of lime and boron has also significant effect on the yield of sprouting broccoli. Data have been presented in table 2 . The maximum yield of sprouting broccoli was recorded 16.16 with the use of lime at 450 $\mathrm{kg} / \mathrm{ha}$ and boron at $30 \mathrm{~kg} / \mathrm{ha}$ that was found to be $63.30 \%$ higher at control concentration.

\section{Quality parameters}

The effect of lime fertilizer has the significant effect on vitamin c content of sprouting broccoli. Data have been presented in table 2 . The maximum vitamin $\mathrm{C}$ of sprouting broccoli was recorded $67.42 \mathrm{mg} / 100 \mathrm{~g}$ with the use of $450 \mathrm{~kg} / \mathrm{ha}$ lime at that was found to be $19.37 \%$ higher over the no lime concentration. The effect of boron at different doses has the significant effect on the vitamin c content of sprouting broccoli. Data have been presented in table 2. The maximum vitamin c of sprouting broccoli was recorded $69.46 \mathrm{mg} / 100 \mathrm{~g}$ with the use of boron at 37.5 $\mathrm{kg} / \mathrm{ha}$ that was found to be $21.87 \%$ higher at no boron application. The interaction effect of lime and boron has also significant effect on the vitamin $\mathrm{C}$ content of sprouting broccoli. Data have been presented in table 2. The maximum vitamin $\mathrm{C}$ content of sprouting broccoli was recorded $68.69 \mathrm{mg} / 100 \mathrm{~g}$ with the use of lime at $450 \mathrm{~kg} / \mathrm{ha}$ and boron at 37.5 $\mathrm{kg} / \mathrm{ha}$ that was found to be $23.48 \%$ higher at lime $450 \mathrm{~kg} / \mathrm{ha}$ and no boron concentration. This may be due to external factors like light intensity, latitude, salt and nitrogen supply (Hewitt et al., 1950).

The effect of lime fertilizer has significant effect on vitamin A content of sprouting broccoli. Data have been presented in table 2 . The maximum vitamin A of sprouting broccoli was recorded $175.87 \mathrm{IU} / 100 \mathrm{~g}$ with the use of $450 \mathrm{~kg} / \mathrm{ha}$ lime that was found to be $29.47 \%$ higher over the no lime concentration. The effect of boron at different doses has the significant effect on the vitamin A content of sprouting broccoli. Data have been presented in table 2 .

The maximum vitamin A of sprouting broccoli was recorded $164.10 \mathrm{IU} / 100 \mathrm{~g}$ with the use of boron at $15 \mathrm{~kg} / \mathrm{ha}$ that was found to be $29.46 \%$ higher at no boron application. The interaction effect of lime and boron has also the significant effect on the vitamin A content of sprouting broccoli. Data have been presented in table 2 .

The maximum vitamin A content of sprouting broccoli was recorded $192.23 \mathrm{IU} / 100 \mathrm{~g}$ with the use of lime at $450 \mathrm{~kg} / \mathrm{ha}$ and boron at 15 $\mathrm{kg} / \mathrm{ha}$ that was found to be $46.75 \%$ higher at control concentration. 


\section{Economic analysis}

Cost and return analysis were done according to the procedure of Choudhary et al., (2009). The detailed economic analysis has been shown in table 3. The input and over head costs were recorded for all the treatments calculated on per hectare basis. The total cost production ranged from Rs. 56339 to Rs. 60868 per hectare. Among the treatments, the variation was due to the cost of various doses of lime and boron fertilizers. The total production cost was highest (Rs. 60868) in case of $450 \mathrm{~kg}$ lime $+37.5 \mathrm{~kg}$ of boron and the lowest (Rs. 56339) was obtained from the control. The highest gross return (Rs. 210080 per hectare) was obtained from $450 \mathrm{~kg}$ lime + $30 \mathrm{~kg}$ boron treatment combination and lowest gross return (Rs. 77090) was recorded from the control. Gross returns were the total income through the sale of sprouting broccoli (head) @ Rs. 13000 per ton. The highest net return (Rs. 127928) was obtained from 450 $\mathrm{kg} / \mathrm{ha}$ lime $+37.5 \mathrm{~kg} / \mathrm{ha}$ boron treatment combination. The highest benefit cost ratio (3.46) was obtained from $450 \mathrm{~kg} / \mathrm{ha}$ lime +30 $\mathrm{kg} / \mathrm{ha}$ boron. The lowest benefit cost ratio (1.36) was recorded from control.

Table.1 Effect of lime and boron on different growth parameters

\begin{tabular}{|c|c|c|c|c|c|c|c|c|c|}
\hline Treatments & $\begin{array}{l}\text { Plant } \\
\text { Height } \\
\text { (cm) }\end{array}$ & $\begin{array}{l}\text { Leaf } \\
\text { length } \\
(\mathrm{cm})\end{array}$ & $\begin{array}{l}\text { Leaf } \\
\text { width } \\
(\mathrm{cm})\end{array}$ & $\begin{array}{l}\text { Number } \\
\text { of leaves }\end{array}$ & $\begin{array}{l}\text { Plant } \\
\text { Spread } \\
(\mathrm{cm})\end{array}$ & $\begin{array}{l}\text { Days to } \\
\text { Harvest }\end{array}$ & $\begin{array}{l}\text { Fresh } \\
\text { weight } \\
\text { of } \\
\text { head (g) }\end{array}$ & $\begin{array}{l}\text { Head } \\
\text { Diameter } \\
(\mathrm{cm})\end{array}$ & $\begin{array}{l}\text { Head dry } \\
\text { weight(g) }\end{array}$ \\
\hline \multicolumn{10}{|l|}{ Lime } \\
\hline LO & 33.90 & 28.35 & 20.56 & 20 & 57.55 & 59.57 & 304.1 & 11.23 & 22.92 \\
\hline L450 & 37.80 & 30.57 & 21.59 & 22 & 62.10 & 60.52 & 452.00 & 14.11 & 20.37 \\
\hline SEm \pm & 0.09 & 1.07 & 0.45 & 0.35 & 0.71 & 0.23 & 6.48 & 0.12 & 0.18 \\
\hline $\mathrm{CD}(\mathrm{P}=0.05)$ & 0.25 & NS & NS & 1.04 & 2.09 & 0.68 & 19.13 & 0.35 & 0.52 \\
\hline \multicolumn{10}{|l|}{ Boron } \\
\hline $\mathbf{B}_{0}$ & 36.60 & 26.76 & 19.73 & 18 & 51.70 & 59.17 & 326.59 & 10.70 & 16.14 \\
\hline $\mathbf{B}_{7.5}$ & 39.20 & 31.05 & 20.17 & 19 & 61.14 & 58.21 & 345.85 & 10.94 & 18.51 \\
\hline$B_{15}$ & 39.20 & 34.54 & 23.00 & 23 & 62.45 & 61.54 & 361.13 & 15.06 & 25.94 \\
\hline $\mathbf{B}_{22.5}$ & 39.80 & 27.12 & 20.27 & 21 & 55.70 & 60.33 & 447.53 & 10.49 & 22.68 \\
\hline $\mathbf{B}_{30}$ & 39.30 & 25.75 & 21.30 & 21 & 57.36 & 60.22 & 450.43 & 18.81 & 21.99 \\
\hline$B_{37.5}$ & 38.70 & 31.56 & 21.99 & 22 & 62.70 & 61.10 & 445.53 & 15.03 & 24.60 \\
\hline SEm \pm & 0.15 & 1.85 & 0.77 & 0.61 & 1.23 & 0.40 & 11.22 & 0.21 & 0.31 \\
\hline $\mathrm{CD}(\mathrm{P}=0.05)$ & 0.44 & 5.46 & NS & 1.80 & 3.62 & 1.18 & 33.13 & 0.61 & 0.91 \\
\hline \multicolumn{10}{|c|}{ Interaction effect of Lime $x$ Boron } \\
\hline $\mathbf{L}_{0} \mathbf{B}_{0}$ & 34.70 & 24.08 & 18.76 & 17 & 53.08 & 56.86 & 335.05 & 8.99 & 16.35 \\
\hline $\mathbf{L}_{0} \mathbf{B}_{7.5}$ & 36.90 & 32.06 & 19.18 & 17 & 61.86 & 57.42 & 356.76 & 10.37 & 18.79 \\
\hline $\mathbf{L}_{0} \mathbf{B}_{15}$ & 39.30 & 34.55 & 21.11 & 22 & 60.47 & 60.81 & 394.53 & 12.55 & 25.59 \\
\hline $\mathbf{L}_{0} \mathbf{B}_{22.5}$ & 38.60 & 25.82 & 19.40 & 20 & 54.12 & 60.25 & 442.98 & 13.59 & 26.28 \\
\hline $\mathbf{L}_{0} \mathbf{B}_{30}$ & 39.90 & 25.65 & 20.14 & 22 & 53.99 & 60.31 & 455.16 & 13.98 & 27.40 \\
\hline $\mathbf{L}_{0} \mathbf{B}_{37.5}$ & 39.70 & 27.93 & 22.76 & 21 & 55.77 & 60.77 & 509.61 & 13.59 & 28.09 \\
\hline$L_{450} B_{0}$ & 39.82 & 29.44 & 20.69 & 21 & 64.31 & 61.49 & 518.14 & 14.41 & 28.42 \\
\hline $\mathbf{L}_{450} \mathbf{B}_{7.5}$ & 36.67 & 30.05 & 21.15 & 25 & 58.43 & 58.99 & 545.70 & 14.52 & 27.22 \\
\hline$L_{450} B_{15}$ & 39.53 & 34.53 & 23.89 & 24 & 64.42 & 62.67 & 567.72 & 15.07 & 29.29 \\
\hline $\mathbf{L}_{450} \mathbf{B}_{22.5}$ & 42.90 & 28.42 & 21.13 & 22 & 57.28 & 60.41 & 572.08 & 15.39 & 29.08 \\
\hline SEm \pm & 0.21 & 2.62 & 1.09 & 0.86 & 1.74 & 0.56 & 15.87 & 0.29 & 0.43 \\
\hline $\mathrm{CD}(\mathrm{P}=0.05)$ & 0.62 & NS & NS & 2.55 & 5.12 & 1.66 & 46.85 & 0.86 & 1.28 \\
\hline
\end{tabular}


Table.2 Effect of lime and boron on different yield and quality parameters

\begin{tabular}{|c|c|c|c|c|c|c|}
\hline Treatments & $\begin{array}{l}\text { Head Dry } \\
\text { Weight } \\
(\%)\end{array}$ & $\begin{array}{l}\text { Fresh Weight } \\
\text { of Secondary } \\
\text { shoots (g) }\end{array}$ & $\begin{array}{l}\text { Yield/ } \\
\text { plot (kg) }\end{array}$ & $\begin{array}{l}\text { Yield } \\
(\mathrm{t} / \mathrm{ha})\end{array}$ & $\begin{array}{l}\text { Vitamin C } \\
(\mathrm{mg} / \mathbf{1 0 0 g})\end{array}$ & $\begin{array}{l}\text { Vitamin A } \\
(\mathrm{mg} / \mathbf{1 0 0 g})\end{array}$ \\
\hline \multicolumn{7}{|l|}{ Lime } \\
\hline Lo & 8.55 & 161.00 & 2.09 & 4.43 & 52.22 & 124.15 \\
\hline L450 & 9.22 & 219.16 & 6.02 & 5.12 & 67.42 & 175.87 \\
\hline SEm \pm & 0.18 & 1.38 & 0.09 & 0.11 & 0.48 & 0.49 \\
\hline $\mathrm{CD}(\mathrm{P}=0.05)$ & 0.52 & 4.06 & 0.29 & 0.42 & 1.40 & 1.44 \\
\hline \multicolumn{7}{|l|}{ Boron } \\
\hline $\mathbf{B}_{0}$ & 7.50 & 130.51 & 2.90 & 4.67 & 50.09 & 126.75 \\
\hline $\mathbf{B}_{7.5}$ & 7.91 & 186.86 & 4.45 & 5.84 & 53.84 & 138.53 \\
\hline $\mathbf{B}_{15}$ & 10.49 & 215.25 & 5.35 & 7.00 & 59.87 & 164.10 \\
\hline $\mathbf{B}_{22.5}$ & 8.67 & 200.10 & 3.52 & 5.90 & 61.68 & 152.37 \\
\hline $\mathbf{B}_{30}$ & 8.90 & 200.06 & 4.61 & 6.41 & 65.10 & 158.57 \\
\hline $\mathbf{B}_{37.5}$ & 9.83 & 207.68 & 3.66 & 5.86 & 69.46 & 159.73 \\
\hline SEm \pm & 0.30 & 2.38 & 0.13 & 0.45 & 0.82 & 0.84 \\
\hline $\mathrm{CD}(\mathbf{P}=0.05)$ & 0.90 & 7.04 & 0.41 & 0.67 & 2.43 & 2.49 \\
\hline \multicolumn{7}{|c|}{ Interaction effect of Lime $x$ Boron } \\
\hline $\mathbf{L}_{\mathbf{0}} \mathbf{B}_{\mathbf{0}}$ & 7.49 & 108.62 & 2.18 & 5.93 & 51.76 & 102.36 \\
\hline $\mathbf{L}_{0} \mathbf{B}_{7.5}$ & 7.26 & 160.52 & 2.52 & 8.11 & 59.52 & 111.25 \\
\hline $\mathbf{L}_{0} \mathbf{B}_{15}$ & 8.67 & 178.81 & 3.38 & 9.33 & 60.13 & 135.98 \\
\hline $\mathbf{L}_{0} \mathbf{B}_{22.5}$ & 8.75 & 182.84 & 3.61 & 10.11 & 65.16 & 130.40 \\
\hline $\mathbf{L}_{\mathbf{0}} \mathbf{B}_{\mathbf{3 0}}$ & 8.89 & 196.65 & 4.74 & 13.33 & 67.43 & 131.94 \\
\hline $\mathbf{L}_{0} \mathbf{B}_{37.5}$ & 8.54 & 198.53 & 4.76 & 12.96 & 63.78 & 132.99 \\
\hline $\mathbf{L}_{450} \mathbf{B}_{0}$ & 8.92 & 202.40 & 4.50 & 11.85 & 60.21 & 151.15 \\
\hline $\mathbf{L}_{450} \mathbf{B}_{7.5}$ & 9.06 & 213.21 & 5.13 & 12.69 & 57.17 & 165.81 \\
\hline $\mathbf{L}_{450} \mathbf{B}_{15}$ & 9.31 & 221.70 & 5.24 & 12.88 & 60.05 & 192.23 \\
\hline $\mathbf{L}_{450} \mathbf{B}_{22.5}$ & 10.50 & 247.35 & 5.43 & 14.81 & 67.19 & 174.33 \\
\hline $\mathbf{L}_{450} \mathbf{B}_{30}$ & 11.30 & 273.47 & 6.52 & 16.16 & 61.77 & 185.20 \\
\hline $\mathbf{L}_{450} \mathbf{B}_{37.5}$ & 11.11 & 236.83 & 6.09 & 15.93 & 68.69 & 186.47 \\
\hline SEm \pm & 0.43 & 3.37 & 0.19 & 0.32 & 1.16 & 1.19 \\
\hline $\mathrm{CD}(\mathrm{P}=0.05)$ & 1.2 & NS & 0.58 & 0.78 & 3.43 & 3.52 \\
\hline
\end{tabular}


Table.3 Economics of sprouting broccoli production with lime and boron combined application

\begin{tabular}{|c|c|c|c|c|c|}
\hline $\begin{array}{l}\text { Treatment } \\
\text { combinations }\end{array}$ & $\begin{array}{l}\text { Yield } \\
\text { (t/ha) }\end{array}$ & $\begin{array}{ll}\text { Gross } & \text { return } \\
\text { (Rs./ha) } & \end{array}$ & $\begin{array}{l}\text { Total cost of } \\
\text { production } \\
\text { (Rs./ha) }\end{array}$ & $\begin{array}{l}\text { Net Return } \\
\text { (Rs./ha) }\end{array}$ & $\begin{array}{l}\text { Benefit } \\
\text { cost ratio } \\
(\mathrm{BCR})\end{array}$ \\
\hline \multicolumn{6}{|c|}{ Interaction effect of Lime $x$ Boron } \\
\hline $\mathbf{L}_{0} \mathbf{B}_{0}$-Control & 5.93 & 77090 & 56339 & 20751 & 1.36 \\
\hline $\mathbf{L}_{0} \mathbf{B}_{7.5}$ & 8.11 & 144430 & 57161 & 87269 & 2.52 \\
\hline $\mathbf{L}_{0} \mathbf{B}_{15}$ & 9.33 & 173290 & 57457 & 115833 & 3.01 \\
\hline $\mathbf{L}_{0} \mathbf{B}_{22.5}$ & 10.11 & 117390 & 57737 & 59653 & 2.03 \\
\hline $\mathbf{L}_{0} \mathbf{B}_{30}$ & 13.33 & 144430 & 58687 & 85743 & 2.46 \\
\hline $\mathbf{L}_{0} \mathbf{B}_{37.5}$ & 12.96 & 168480 & 59526 & 108954 & 2.83 \\
\hline $\mathbf{L}_{450} \mathbf{B}_{0}$ & 11.85 & 145050 & 59805 & 103030 & 2.42 \\
\hline $\mathbf{L}_{450} \mathrm{~B}_{7.5}$ & 12.69 & 164970 & 60085 & 132221 & 2.74 \\
\hline $\mathbf{L}_{450} B_{15}$ & 12.88 & 162500 & 59470 & 149492 & 2.73 \\
\hline $\mathbf{L}_{450} B_{22.5}$ & 14.81 & 192530 & 60309 & 146222 & 3.19 \\
\hline$L_{450} B_{30}$ & 16.16 & 210080 & 60588 & 120318 & 3.46 \\
\hline $\mathbf{L}_{450} \mathbf{B}_{37.5}$ & 15.93 & 207090 & 60868 & 127928 & 3.40 \\
\hline
\end{tabular}

In conclusion, the study showed that the use of lime and boron enhanced the crop growth in October sown and recorded the yield/plot of $6.43 \mathrm{~kg}$ maximum with the use of 450 $\mathrm{kg} / \mathrm{ha}$ lime and $30 \mathrm{~kg} / \mathrm{ha}$ boron, hence it may be concluded that use of lime and boron at $450 \mathrm{~kg} / \mathrm{ha}$ and $30 \mathrm{~kg} / \mathrm{ha}$ respectively, and boron at the rate $30 \mathrm{~kg} / \mathrm{ha}$ gives fresh weight of head, head diameter, weight of secondary shoots. It may be concluded from the findings of the present study that use of $450 \mathrm{~kg} / \mathrm{ha}$ lime and $30 \mathrm{~kg} / \mathrm{ha}$ of boron gives higher yield of $6.43 \mathrm{~kg}$ and application of lime at $450 \mathrm{~kg} / \mathrm{ha}$ and lime at $37.5 \mathrm{~kg} / \mathrm{ha}$ gives maximum net return of Rs.127928/ha because of boron mobility in sprouting broccoli.

\section{References}

A.L Miller, R.H. and Keeny D.R. 1982 Methods of Soil Analysis, Part II, American Society of Agronomy and Soil Science Society of America Madison, U.S.A.

Brahma, S., D.B. Phookan, B.P. Gautam and D.K. Bora. 2002. Effect of nitrogen, phosphorus and potassium on growth and yield of broccoli (Brassica oleracea L. var. italica) cv. Pusa broccoli KTS-I. Indian J. Agril. Sci. Soc., 15(1): 104-106.

Chandra G. Verma, T.S. and Sharma, S. 2007 Influence of B and Farmyard Manure on available Boron and Exchangeable Calcium and their removal by Cauliflower in the B-deficient soils of Himachal Pradesh. Journal of Indian Society Soil Science 55 (1): 62-63.

Chaudhury S.G. and Debnath A. 2008 Effect of liming on retention an availability of boron in entisol and alfisol. Journal of Indian Society Soil Science 56 1: 64-70

Cox, D. R. 1958. Two further applications of a model for binary regression. Biometrika, 45(3/4), 562-565.

Fisher, R. A., and Yates, F. 1963. Statistical Tables: For Biological, Agricultural and Medical Research. Oliver and Boyd.

Godvindan, P.R. 1989 Influence of boron on yield and content of carbohydrate in tomato fruits Canadian Science, 21: 14- 
15.

Hewitt, L. F. 1950. Oxidation Reduction Potentials In Bacteriology And Biochemistry. ES Livingstone: Edinburgh.

Jana, J.C 2004 Effect of micronutrients on yield and quality of cauliflower seeds. Seed Response, 32 (1): 98-100.

Kotur, S.C. 1993 Response of cauliflower to lime and boron in a boron deficient soil. Indian Journal of Horticulture 50 (4): 344-349.

Kumar, S. and Choudhary, D.R. 2002. Effect of FYM, molybdenum and boron application on yield attributes and yield of cauliflower. Crop-Research-Hisar, 24(3): 494-496.

Kushwaha A.K Singh S and Singh R.N. 2009 Available nutrients and response of lentil Lense esculenta to boron application in rainfed upland soils of Ranchi. Journal of Indian Society Soil Science 57 (2):pp 21 -22.

Mishra, H. P. and B. P. Singh, 1984. Influence of foliar application of nitrogen, boron and Gibberellic acid on the yield contributing characters and yield of cauliflower. Bangladesh Horticulture. 12: 21-25.

Panse, V.G. and Sukhatme, P.V. 1998. Statistical methods for agricultural workers ICAR, New Delhi.

Pizetta, L. C., Ferreira, M. E., Cruz, M. C. P. D., and Barbosa, J. C. 2005. Response of boron fertilization on broccoli, cauliflower and cabbage planted in sandy soil. Horticultura Brasileira,
23(1), 51-56.

Prasad, K.K., S. Singh, Singh, K.P., Choudhary, B.M. and Singh, S. 2000. Yield of cauliflower with boron application. Journal of Research, Birsa Agricultural University, 12(1): 117118.

Saha A Mandal B. and Mukhopadhyay P. 1999 Growth analysis and yield study of yellow Sarson under different mode of boron and molybdenum fertilization in a deficient soil environment. Indian Journal of Agriculture Science 69 (9): 631-5.

Sanjay, K., D.R. Chawdhury and S. Kumar, 2002. Effect of FYM, molybdenum and boron application on yield attributes and yields of cauliflower. Crop Research. 24: 494-496.

Sharma, P. N. and Ramachandra, T., 1991, Effects of boron deficiency and recovery on water retentions and photosynthesis in cauliflower. Indian J. Expt. Biol., 29 (10): 967-970.

Sharma, S.K. 1999 Effect of boron and calcium on seed production of bell pepper. Vegetable Science 26 (1): 8788.

Sharma, S.K. 2002 Effect of boron and molybdenum on seed production of cauliflower. Indian Journal of Horticulture 59 (2): 177-180.

Sharma, S.K. 2002 Effect of boron and molybdenum on seed production of cauliflower. Indian Journal of Horticulture 59 (2): 177-180.

\section{How to cite this article:}

Riman Saha Chowdhury, Monika Kumari, J.C. Jana, Shibnath Basfore and Subhamoy Sikder. 2019. Effect of Lime and Boron on Growth and Yield of Sprouting Broccoli under SubHimalayan Foot Hills of West Bengal, India. Int.J.Curr.Microbiol.App.Sci. 8(01): 2506-2516. doi: https://doi.org/10.20546/ijcmas.2019.801.265 